\title{
PENGARUH METODE PROBLEM SOLVING DAN MOTIVASI \\ TERHADAP HASIL BELAJAR MATEMATIKA SISWA \\ KELAS V SDN 04 MUARO SEI LOLO \\ KABUPATEN PASAMAN
}

\author{
Arjun, Risda Amini, Firman. \\ Email: firman@,konselor.org
}

\begin{abstract}
This research aimed to reveal the influence of problem solving method and motivation to mathematics learning outcomes in the fifth grade of elementary school on the subjects of multiplication and division of fractions. The type of this study was experimental research using quantitative method of quasi experiment. The design of the research was explained in the form of $2 \times 2$ factorial. The populations of the research were all fifth grade students of elementary school in Sub-district of Mapat Tunggul Selatan belonging to a group of high school consisted of 7 schools. The technique of sample collecting used was purposive sampling. The data of the research were obtained from questionnaire of motivation and mathematics learning outcomes. The technique of data analysis was done using two-ways ANOVA technique. The result of the analysis showed that: (1) there were differences of the learning outcomes of multiplication and division of fractions between students who were taught problem solving methods and students who were taught in a conventional way, with significance value of 0,000 . (2) There were differences of the learning outcomes of multiplication and division of fractions between students who had high motivation and the learning outcomes of students who had low motivation, with significance value of 0,001 . (3) There wasn't an interaction between learning methods and students' motivation to the students' learning outcomes of multiplication and division of fractions, with significance value of 0,438 .
\end{abstract}

Key words: Problem solving, motivation, mathematics learning outcomes of fifth grade of elementary school

\section{Pendahuluan}

Pentingnya matematika dalam kehidupan dapat dirasakan dan dilihat dari diajarkannya pelajaran matematika di setiap jenjang pendidikan. Bahkan untuk mempelajari ilmu lain diperlukan keterampilan matematika yang sesuai. Hal ini berarti bahwa kemampuan matematika menjadi harus dimiliki oleh setiap masyarakat terutama siswa di sekolah. Menyadari akan peranan mata pelajaran matematika dalam kehidupan sehari-hari dan khususnya bagi siswa Sekolah Dasar (SD), seharusnya dalam pembelajaran matematika siswa merasa tertarik dan 
mempunyai motivasi yang tinggi dalam belajar matematika.

Guru sebagai pendidik juga harus mampu menciptakan suasana belajar yang dapat membangkit motivasi siswa dengan menggunakan metode pembelajaran. Kemampuan yang baik dalam memilih metode pembelajaran dan membuat rencana pembelajaran yang dapat memancing siswa untuk berpikir logis, kritis, dan sistematis, serta memudahkan siswa memahami konsep pembelajaran sehingga dapat menggunakan nya dalam kehidupan sehari-hari, sebagai bekal untuk menghadapi tantangan perkembangan dan perubahan zaman.

Ketika seorang siswa dihadapkan pada suatu persoalan matematika untuk diselesaikan, pada saat yang sama seorang siswa tersebut diharapkan untuk menggunakan konsep yang telah mereka miliki dari berbagai sumber, mengkaitkan konsep-konsep tersebut dan mengaplikasikan untuk memecahkan masalah. Kemampuan pemecahan masalah memegang peranan penting dalam menyelesaikan masalah tersebut untuk menyusun langkah-langkah penyelesaian menurut masalah yang dimiliki siswa yang dibutuhkan untuk membuat suatu kesimpulan pemecahan masalah.

Kenyataan di lapangan bahwa permasalahan di kelas V SDN 04 Muaro Sei Lolo Kabupaten Pasaman bahwa pada saat guru menjelaskan pelajaran matematika dengan materi perkalian dan pembagian pecahan kepada siswa, dengan memberikan beberapa contoh soal dan penyelesaiannya. Kemudian guru memberikan tugas dengan soal yang serupa dengan apa yang dijelaskan, beberapa orang siswa telah mampu menyelesaikan tugas tersebut. Pada saat guru memberikan tugas dengan soal pemecahan masalah berbeda dengan contoh soal yang dijelaskan kepada siswa, terlihat siswa kebingungan untuk menyelesaikannya. Siswa belum mampu untuk menyelesaikan soal pemecahan masalah tersebut. Melihat kondisi siswa yang kebingungan maka guru memberikan penjelasan-penjelasan untuk penyelesaian soal tersebut, namun satu, dua orang siswa saja yang bisa menyelesaikannya, sedangkan untuk soal berikutnya siswa tersebut kebingungan lagi. 
Ditinjau dari permasalahan tersebut bahwa dalam pembelajaran pecahan siswa merasa kesulitan dalam memahami perkalian dan pembagian pecahan, siswa hanya bisa menyelesaikan soal yang diberikan contoh soalnya dan kesulitan dalam menyelesaikan soal pemecahan masalah, siswa belum diajarkan untuk menemukan masalah dalam pembelajaran matematika dan mencari solusi penyelesaian masalah tersebut. Pembelajaran tidak diarahkan kepada kemampuan siswa dalam memecahkan masalah matematika, terutama masalah yang ditemui siswa dalam kehidupan sehari-hari. Pelaksanaan pembelajaran yang diberikan guru belum bervariasi dan masih konvensional.

Sukayati dan Marfuah (2009:6) menyatakan bahwa tidak sedikit guru yang membelajarkan perkalian dan pembagian pecahan kepada siswa hanya dengan menjelaskan bahwa hasil dapat diperoleh dengan mengalikan pembilang dengan pembilang dan mengalikan penyebut dengan penyebut. Penjelasan yang disampaikan guru kurang membangkitkan motivasi siswa.
Sumiati dan Asra (2009:236) menyatakan bahwa "motivasi dapat memberikan semangat (dorongan) yang luar biasa terhadap seseorang untuk berperilaku dan dapat memberikan arah dalam belajar. Motivasi ini pada dasarnya merupakan keinginan (want) yang ingin dipenuhi (dipuaskan), maka ia timbul jika ada rangsangan, baik karena adanya kebutuhan (needs) maupun minat (interest) terhadap sesuatu". Motivasi siswa dalam pembelajaran matematika sangat diharapkan agar dapat digunakan sebagai penunjang proses pembelajaran.

Motivasi juga memfasilitasi siswa dalam membangun pengatahuan secara utuh, sebagai contoh pengetahuan itu bisa diperoleh dari matematika. Pembelajaran matematika yang diberikan kepada siswa hendaknya dengan pemecahan masalah. Wahyudin (2008:63) menyatakan: ditingkat kelas 5-8, kurikulum hendaknya memasukkan pengalaman pengalaman yang banyak dan beraneka ragam dengan pemecahan masalah sehingga siswa mampu, (1) menggunakan metode-metode peme- 
cahan masalah untuk meneliti dan memahami muatan matematis; (2) memformulasi permasalahan dari situasi-situasi di dalam dan di luar matematika; (3) membangun dan menerapkan berbagai strategi untuk memecahkan masalah, dengan penekanan pada permasalahan multilangkah dan non-rutin; (4) menguji dan menginterpretasi hasil-hasil dengan memperhatikan situasi permasalahan sebenarnya; menggeneralisasi solusi dan strategi ke situasi-situasi masalah baru; (6) memperoleh kepercayaan diri dalam menggunakan matematika secara bermakna.

Perlu adanya suatu upaya untuk meningkatkan kemampuan pemecahan masalah siswa, seperti merancang suatu pembelajaran yang membiasakan siswa untuk mengkonstruksi sendiri pengetahuan nya, sehingga siswa lebih memahami konsep yang diajarkan. Salah satu metode yang diduga dapat mengatasi masalah di atas adalah dengan menggunakan metode pemecahan masalah (problem solving)

Problem Solving merupakan metode yang dapat digunakan dalam pembelajaran matematika, karena dalam proses pembelajaran maupun penyelesaian, siswa dimungkinkan memperoleh pengalaman mengguna kan pengetahuan serta keterampilan yang sudah dimiliki untuk diterapkan pada pemecahan masalah yang bersifat tidak rutin (Suherman, dkk, 2003:89). Untuk menyelesaikan suatu masalah, siswa tersebut harus menguasai hal-hal yang telah dipelajari sebelumnya, yaitu menge nai pengetahuan, keterampilan, dan pemahaman.

Pendapat yang dikemukakan oleh Wahyudin (2008:58) "seorang guru yang mengajarkan pelajaran pemecahan masalah seharusnya memasukkan beberapa perilaku ke dalam pelajaran, deskripsi guru itu sudah meraba-raba menuju solusi, pertanyaan-pertanyaan mengenai kelebihan dan kelemahan dari mode pemecahan, dan petunjuk tentang cara mendapatkan feedback tanpa meminta bantuan kepada guru". Pembelajaran dengan metode pro blem solving mengarahkan siswa untuk memahami dan memiliki keterampilan pemecahan masalah.

Polya (1973 : xvi-xvii) menjelaskan langkah-langkah metode problem solving, (1) understand the 
problem; (2) devise a plan; (3) carry out the plan; (4) look back dalam bahasa indonesianya (1) memahami masalah; (2) menyusun rencana; (3) melaksanakan rencana; (4) lihat kembali.

Keunggulan dari metode problem solving ini adalah, membuat siswa mampu menghadapi masalah, melatih siswa menyelesaikan masalahnya secara terampil, mengembangkan kemampuan berpikir siswa menjadi lebih kreatif.

Penelitian ini bertujuan untuk mengungkapkan pengaruh metode problem solving dan motivasi terhadap hasil belajar matematika di kelas V SD pada materi perkalian dan pembagian pecahan.

\section{Metode Penelitian}

Penelitian ini menggunakan metode kuantitatif dalam bentuk quasi experiment. Desain penelitian diterapkan pada situasi belajar yang berbeda yakni dengan pembelajaran metode problem solving pada kelas eksperimen dan konvensional pada kelas kontrol. Desain ini diuraikan ke dalam bentuk faktorial $2 \times 2$.

Tabel 1. Desain Penelitian

\begin{tabular}{|c|c|c|}
\hline \multirow{2}{*}{$\begin{array}{c}\text { Motivasi } \\
\text { Belajar }\end{array}$} & \multicolumn{2}{|c|}{ Metode } \\
\cline { 2 - 3 } & $\begin{array}{c}\text { Problem } \\
\text { Solving } \mathbf{B}_{1}\end{array}$ & $\begin{array}{c}\text { Konvensionaran } \\
\mathbf{B}_{2}\end{array}$ \\
\hline Tinggi $\mathbf{A}_{1}$ & $\mathbf{A}_{1} \mathbf{B}_{1}$ & $\mathbf{A}_{1} \mathbf{B}_{2}$ \\
\hline
\end{tabular}

\begin{tabular}{|c|c|c|}
\hline $\begin{array}{c}\text { Rendah } \\
\mathbf{A}_{\mathbf{2}}\end{array}$ & $\mathbf{A}_{\mathbf{2}} \mathbf{B}_{\mathbf{1}}$ & $\mathbf{A}_{\mathbf{2}} \mathbf{B}_{\mathbf{2}}$ \\
\hline
\end{tabular}

(Sumber: diadaptasi dari Suwanda, 2011: 123)

Keterangan:

$\mathrm{A}_{1} \mathrm{~B}_{1}$ : hasil belajar perkalian dan pembagian pecahan siswa motivasi tinggi dengan metode problem solving

$\mathrm{A}_{1} \mathrm{~B}_{2}$ : hasil belajar perkalian dan pembagian pecahan siswa motivasi tinggi dengan konvensional

$\mathrm{A}_{2} \mathrm{~B}_{1}$ : hasil belajar perkalian dan pembagian pecahan siswa motivasi rendah dengan metode problem solving

$\mathrm{A}_{2} \mathrm{~B}_{2}$ : hasil belajar perkalian dan pembagian pecahan siswa motivasi rendah dengan konvensional

Populasi dalam penelitian ini yaitu seluruh siswa kelas V SD di Kecamatan Mapat Tunggul Selatan (MTS) Kabupaten Pasaman yang terdaftar pada tahun ajaran 2015/2016. Sampel penelitian diambil dengan cara purposive sampling. Variable penelitian ini yaitu, (a) metode problem solving. (b) motivasi. (c) hasil belajar matematika.

Jenis data yang digunakan pada penelitian ini yaitu data yang diperoleh langsung dari responden berupa angket motivasi dan tes hasil belajar matematika. Sumber data dalam penelitian ini yaitu siswa pada kelas kontrol dan kelas eksperimen. 
Instrumen yang diguna kan dalam penelitian ini adalah sebagai berikut: (1) Angket motivasi belajar, menggunakan skalaLikert. (2) Tes hasil belajar siswa, Tes hasil belajar dirancang untuk mengetahui kemampuan kognitif siswa setelah dilaksanakan penelitian.

Menguji validitas setiap item angket motivasi dan soal tes hasil belajar maka skor-skor yang ada pada butir yang dimaksud dikorelasikan dengan skor totalnya, digunakan rumus Produk Momen Pearson dan dibantu dengan program SPSS versi 17.

Selanjutnya dihitung relibialitas angket motivasi dan soal tes hasil belajar. Suatu item dapat dikatakan reliabel apabila beberapa kali pengujian menunjukan hasil yang relatif sama. Keefisienan reliabilitas digunakan rumus alpha dan dibantu dengan program SPSS versi 17.

Teknik analisis data yang akan digunakan pada penelitian ini adalah Teknik ANOVA dua arah dengan sel tidak sama. Agar memudahkan dalam menganalisis data tersebut maka sebelumnya perlu dilakukan uji persyaratan ANOVA, kemudian dilajutkan dengan uji hipotesis dengan ANOVA dua arah.

Sebelum dilakukan pengujian hipotesis penelitian, terlebih dahulu dilakukan pengujian normalitas sebagai persyaratan analisis yang diolah dengan program komputer statistik SPSS. Jika pengujian tersebut terpenuhi, maka pengujian dengan menggunakan program SPSS dilajutkan untuk menguji Homogenitas. Teknik yang digunakan dalam menganalisis data untuk menguji hipotesis adalah dengan menggunakan Anava Dua Arah. Tujuan dari uji ini adalah untuk mengetahui apakah rata-rata hasil belajar perkalian dan pembagian pecahan siswa kelas eksperimen lebih baik dari rata-rata hasil belajar kelas kontrol.

\section{Hasil Penelitian dan Pembahasan}

\section{a. Hasil Penelitian}

Hasil belajar perkalian dan pembagian pecahan siswa kelas eksprimen dan kelas kontrol baik yang bermotivasi tinggi maupun yang bermotivasi rendah diperoleh setelah dilaksanakan tes akhir terdapat pada table 2 .

Tabel 2. Distribusi Nilai Tes Hasil Belajar Perkalian dan Pembagian 
Pecahan Kelas Eksprimen dan Kelas Kontrol

\begin{tabular}{|c|c|c|c|c|c|c|c|}
\hline T6 & Kans & $\begin{array}{c}\text { Plowiat } \\
\text { neva }\end{array}$ & $\mathrm{s}$ & $x=b$ & $x_{\text {en }}$ & $\begin{array}{l}R=2 \\
\text { ran }\end{array}$ & $\begin{array}{l}\text { Sisa } \\
\text { Foln }\end{array}$ \\
\hline$\frac{\text { Hail }}{\text { ?wisvar }}$ & spoture & $\begin{array}{l}\text { Paspi } \\
\text { Parts }\end{array}$ & & & $\because 3$ & Yis & $y: 5$ \\
\hline \multirow{2}{*}{$\begin{array}{c}\text { È } \\
\text { Fatacas } \\
\text { Foun }\end{array}$} & Fissate & $\begin{array}{l}\text { Ixri } \\
\text { Baid. }\end{array}$ & 32 & $\because$ & $1: 5$ & $\$ 5:$ & $-2,78$ \\
\hline & \multicolumn{2}{|c|}{ Jaelà } & \multicolumn{5}{|l|}{4} \\
\hline \multirow[t]{3}{*}{1} & Eox-ina & Inté & 28 & \multirow{2}{*}{ if } & \multirow{2}{*}{5} & \multirow{2}{*}{625} & SF: \\
\hline & Resas. & Ixad & 13 & & & & $2 x$ \\
\hline & \multicolumn{2}{|c|}{ Juciá } & \multicolumn{5}{|l|}{31} \\
\hline \multirow[t]{3}{*}{1} & Eoxisax & Raid. & 12 & \multirow{2}{*}{ It' } & \multirow{2}{*}{$2: 3$} & \multirow{3}{*}{655} & 315 \\
\hline & Mxase. & Raid. & IS & & & & 61 \\
\hline & \multicolumn{2}{|c|}{ luriv } & \multicolumn{4}{|l|}{ 지 } & \\
\hline
\end{tabular}

Berdasarkan tabel 2, rata-rata hasil belajar perkalian dan pembagian pecahan siswa yang menggunakan pembelajaran dengan metode problem solving lebih tinggi daripada rata-rata hasil belajar perkalian dan pembagian pecahan siswa yang menggunakan pembelajaran konvensional. Hasil belajar perkalian dan pembagian pecahan siswa motivasi tinggi lebih tinggi daripada hasil belajar perkalian dan pembagian pecahan siswa motivasi rendah.

Berdasarkan data simpangan baku maka nilai hasil belajar perkalian dan pembagian pecahan siswa yang menggunakan pembelajaran dengan metode problem solving lebih baik dibanding pembelajaran konvensional. Nilai hasil belajar perkalian dan pembagian pecahan siswa motivasi tinggi lebih baik daripada nilai hasil belajar perkalian dan pembagian pecahan siswa motivasi rendah. Skor maksimum dan minimum hasil belajar perkalian dan pembagian pecahan siswa untuk kelas eksperimen lebih tinggi dibandingkan dengan kelas kontrol dan siswa motivasi tinggi lebih tinggi dibandingkan siswa motivasi rendah.

Uji normalitas dilakukan terhadap nilai tes hasil belajar perkalian dan pembagian pecahan siswa kelas eksprimen dan siswa kelas kontrol, baik yang bermotivasi tinggi maupun yang bermotivasi rendah. Hasil pengujian dapat dilihat pada Tabel 3.

Tabel 3. Uji Normalitas terhadap Nilai Tes Hasil Belajar Perkalian dan Pembagian Pecahan Menggunakan Uji Kolmogorov Smirnov

\begin{tabular}{|c|c|c|c|c|}
\hline $\mathrm{J}: \mathrm{t}$ & Tañted. & Kedix & DI & Szifloxi \\
\hline $\mathrm{Hel}$ & \multirow{2}{*}{ Selice } & Extia & is & gics \\
\hline Petrian & & Int & 3 & 0,3 \\
\hline $\begin{array}{l}\text { In } \\
\text { Peatiget } \\
\text { Pecaur }\end{array}$ & \multirow{2}{*}{$\begin{array}{c}\text { Yxina:i Bitie } \\
\text { Suns }\end{array}$} & 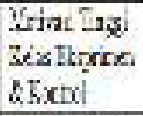 & 万) & $96:$ \\
\hline & & 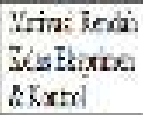 & $3 !$ & $0,5 ?$ \\
\hline
\end{tabular}

Berdasarkan tabel 3 diperoleh bahwa nilai signifikansi semua data $>0,05$ sehingga dapat disimpulkan bahwa data berdistribusi normal.

Uji persyaratan analisis yang dilakukan selanjutnya adalah uji homogenitas variansi dengan 
menggunakan analisis SPSS menurut uji Levene. Hasil pengujian dapat dilihat pada Tabel 4.

Tabel 4. Uji Homogenitas terhadap Nilai Tes Hasil Belajar Perkalian dan Pembagian Pecahan Siswa Menggunakan Uji Levene

\begin{tabular}{|c|c|c|c|c|}
\hline Has] Batsir & Eits & Nowiss & if & Syillyan \\
\hline Kod: & $\begin{array}{l}\text { Byriax } \\
\text { Kindal }\end{array}$ & $\begin{array}{l}\text { Trash } \\
\text { 3eald }\end{array}$ & 2 & $6 \leqslant 4$ \\
\hline Shinzi & $\begin{array}{l}\text { Elarian } \\
\text { Kendi }\end{array}$ & $\begin{array}{l}\text { Thisy } \\
\text { Jeatit: }\end{array}$ & 2 & $0 \pi$ \\
\hline $\begin{array}{l}\text { inceki Norde } \\
\text { danu.Sutani }\end{array}$ & $\begin{array}{l}\text { Howiax } \\
\text { Kend }\end{array}$ & $\begin{array}{l}\text { Tisy } \\
\text { 3kjth }\end{array}$ & 9) & $t, 00$ \\
\hline
\end{tabular}

Berdasarkan Tabel 4 diperoleh bahwa nilai signifikansi semua data $>0,05$, maka dapat disimpulkan data mempunyai variansi yang homogen.

Berdasarkan uji persyaratan analisis, maka dilanjutkan dengan uji hipotesis menggunakan Analisis Variansi (Anava Dua Arah). Pengolahan uji hipotesis dalam penelitian ini dilakukan dengan bantuan SPSS versi 17. Hasil perhitungan dengan uji Anava Dua Arah dapat dilihat dalam Tabel 5.

\section{Tabel 5. Hasil Uji Anava Dua Arah untuk Pengujian Hipotesis Penelitian}

\begin{tabular}{|c|c|c|c|c|}
\hline Hxal B:kły & Judth hatrit & fi & E & 8quilye! \\
\hline 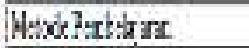 & $18 S 1920$ & 1 & $20, i 17$ & $2 x$ \\
\hline Nx:rai & Eit36 & 1 & 1150 & $2) 1$ \\
\hline 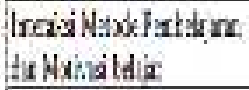 & $\not 2 ; 3$ & ; & 296 & dits \\
\hline
\end{tabular}

Berdasarkan hasil perhitungan uji Anava Dua Arah pada Tabel 2 dapat disimpulkan
1. Perbedaan hasil belajar siswa yang diajar melalui metode problem solving dengan siswa yang diajar secara konvensional pada materi perkalian dan pembagian pecahan.

Hasil uji hipotesis nilai signifikansi 0,000 berarti $\mathrm{H}_{0}$ ditolak berarti terdapat perbedaan hasil belajar perkalian dan pembagian pecahan siswa yang diajar dengan metode problem solving dengan siswa yang diajar dengan konvensional. Hasil belajar siswa terhadap materi perkalian dan pembagian pecahan yang di ajarkan dengan menggunakan metode problem solving lebih baik dari pada hasil belajar siswa yang di ajar secara konvensional. Pembelajaran dengan menggunakan metode problem solving dapat mempengaruhi hasil belajar siswa kepada hasil yang lebih baik.

2. Perbedaan hasil belajar siswa motivasi tinggi dengan siswa motivasi rendah pada materi perkalian dan pembagian pecahan.

Hasil uji hipotesis nilai signifikansi 0,001 berarti $\mathrm{H}_{0}$ ditolak, terdapat perbedaan hasil belajar 
perkalian dan pembagian pecahan siswa motivasi tinggi dengan hasil belajar siswa motivasi rendah. Siswa yang memiliki motivasi belajar yang tinggi, hasil belajarnya akan lebih baik dari pada siswa yang memiliki motivasi belajar yang rendah. Motivasi belajar yang tinggi dapat mempengaruhi hasil belajar siswa ke pada hasil yang lebih baik.

3. Ada atau tidak interaksi antara metode pembelajaran dan motivasi siswa terhadap hasil belajar siswa pada materi perkalian dan pembagian pecahan.

Hasil uji hipotesis nilai signifikansi 0,438 berarti $\mathrm{H}_{0}$ diterima berarti tidak terdapat interaksi antara Metode Pembelajaran dan Motivasi siswa terhadap hasil belajar perkalian dan pembagian pecahan siswa. Tidak terdapatnya interaksi ini menunjukkan bahwa, tanpa memperhatikan motivasi belajar, pembelajaran dengan metode problem solving dapat diterapkan untuk melihat hasil belajar siswa. Hal ini menunjukkan bahwa metode pembelajaran tidak tergantung pada motivasi belajar maupun sebaliknya dalam mempengaruhi hasil belajar siswa.

\section{b. Pembahasan}

Hasil belajar perkalian dan pembagian pecahan siswa yang diajar dengan metode problem solving lebih baik daripada hasil belajar perkalian dan pembagian pecahan siswa yang diajar dengan metode konvensional. Sejalan dengan hasil penelitian yang dilakukan oleh Suhendri dan Mardalena (2015) membuktikan bahwa "terdapat pengaruh metode pembelajaran problem solving terhadap hasil belajar matematika atau hasil belajar matematika siswa yang diajar dengan metode pembelajaran problem solving lebih tinggi dari pada hasil belajar matematika siswa yang diajar dengan pembelajaran konvensional"

Begitu juga dengan hasil penelitian yang dilakukan oleh Ainul (2013) membuktikan bahwa "kelas yang menggunakan metode pembelajaran problem solving lebih signifikan dibandingkan kelas kontrol yang menggunakan pembelajaran konvensional. Hasil belajar siswa yang dimaksud adalah hasil belajar untuk ranah kognitif'. 
Metode problem solving lebih menitik beratkan pada pemecahan masalah artinya siswa sendiri yang sendiri yang menemukan masalahnya, dan mencari solusi penyelesaian masalah tersebut serta membangun pengetahuannya dengan cara mengintegrasikan pengetahuan sebelumnya dengan pengetahuan baru yang sedang mereka pelajari. Selain itu siswa juga dilibatkan bagaimana menemukan sendiri konsep pelajaran dengan bantuan lembar kerja siswa (LKS), sehingga siswa menjadi aktif dan pembelajaran dirasakan lebih bermakna.

Majid (2009: 142) menyatakan bahwa metode problem solving adalah "cara memberikan pengertian dengan menstimulasi anak didik untuk memperhatikan, menelaah dan berfikir tentang suatu masalah untuk selanjutnya menganalisis masalah tersebut sebagai upaya untuk memecahkan masalah".

Pembelajaran dengan metode problem solving siswa dituntut untuk menjelaskan atau mempresentasikan hasil diskusi kelompok. Hal ini bertujuan untuk melatih siswa mengkomunikasikan gagasannya, sehingga pembelajaran lebih menarik karena terjadi saling bertukaran ide dengan kelompok atau siswa yang lain. Proses ini membuat siswa lebih memahami materi dan materi yang telah dipahami akan tersimpan lama dalam memori siswa. Senada apa yang disampaikan oleh Yamin (2009:82-83) menyatakan ciri-ciri pembelajaran problem solving: “(1) siswa bekerja secara individual atau dalam kelompok kecil; (2) tugas yang diselesaikan adalah persoalan realistis untuk dipecahkan; (3) siswa menggunakan berbagai metode jawaban; (4) hasil pemecahan masalah didiskusikan antara semua siswa".

Berdasarkan hasil analisis bahwa terdapat perbedaan hasil belajar siswa yang diajar melalui metode problem solving dengan siswa yang diajar secara konvensional pada materi perkalian dan pembagian pecahan. Sehingga diperoleh hasil belajar perkalian dan pembagian pecahan siswa yang diajar dengan menggunakan metode problem solving lebih baik dari pada hasil belajar perkalian dan pembagian pecahan siswa yang diajar menggunakan konvensional. 
Senada dengan hasil penelitian yang dilakukan Udin dan Hikmah (2013) "terdapat pengaruh metode Problem Solving terhadap hasil belajar siswa pada pelajaran Matematika materi Pecahan".

Hasil penelitian Pait (2012) menunjukkan bahwa "terdapat perbedaan prestasi belajar matematika antara siswa yang mengikuti model pembelajaran problem solving dengan siswa yang mengikuti model pembelajaran konvensional". Ali, dkk (2010) dalam penelitiannya menyatakan bahwa "ada perbedaan yang signifikan antara efektivitas metode pembelajaran konvensional dan metode problem solving dalam pembelajaran Matematika di SD".

Sedikit berbeda dengan hasil penelitian yang dilakukan oleh Yasin (2012) bahwa "tidak ada perbedaan yang signifikan antara kedua kelompok (kelompok eksperimen dan kelompok kontrol) terhadap kemampuan siswa memecahkan masalah, tetapi nilai rata-rata kelompok eksperimen lebih tinggi dibandingkan kelompok kontrol. Hal ini membuktikan bahwa pelaksanaan strategi problem solving dalam pembelajaran berhasil meningkatkan prestasi siswa dan pengetahuan siswa memecahkan masalah di samping secara positif mempengaruhi kemampuan siswa memecahkan masalah".

Hal ini disebabkan karena pada pembelajaran dengan metode problem solving siswa diberikan kesempatan untuk mengeksplorasi pengetahuannya sendiri untuk menghitung perkalian dan pembagian pecahan melalui langkahlangkah kegiatan yang terdapat di LKS. Keterlibatan siswa secara aktif dalam menghitung perkalian dan pembagian pecahan, memberikan pengalaman belajar berupa aktivitas yang melibatkan fisik, mental maupun emosional siswa. Selain itu penggunaan media tali, bangun datar persegi, persegi panjang dan lingkaran membantu siswa memahami materi yang masih abstrak sehingga menciptakan pembelajaran yang bermakna dan menyenangkan.

Berdasarkan pengamatan peneliti selama proses pembelajaran dengan metode problem solving terlihat bahwa siswa mampu menghitung perkalian dan 
pembagian pecaahan dengan tepat.

Pembelajaran dengan metode problem solving memberikan kesempatan kepada siswa untuk bisa menemukan setiap permasalahan dan konsep oleh dirinya sendiri maupun dengan teman kelompoknya.

Kelebihan dari metode problem solving adalah merangsang pengembangan kemampuan berfikir siswa secara kratif dan menyeluruh, karena dalam proses belajarnya, siswa banyak melakukan kegiatan berfikir dengan memahami permasalahan dari berbagai segi dalam rangka mencari pemecahan. Sehingga siswa menemukan sendiri konsep pembelajaran yang dibutuhkan. Konsep yang ditemukan sendiri akan lebih lama bertahan dalam ingatan siswa dan pembelajaran lebih bermakna. Dari penjelasan di atas dapat dikatakan bahwa hal-hal tersebutlah yang merupakan penyebab terjadinya perbedaan hasil belajar perkalian dan pembagian pecahan siswa yang diajar dengan metode problem solving lebih baik daripada siswa yang diajar dengan metode konvensional.
Berdasarkan hasil analisis bahwa terdapat perbedaan hasil belajar siswa motivasi tinggi dengan siswa motivasi rendah pada materi perkalian dan pembagian pecahan. Secara umum hasil belajar perkalian dan pembagian pecahan siswa motivasi tinggi lebih baik daripada siswa motivasi rendah. Hasil penelitian ini senada dengan hasil penelitian yang dilakukan Mulyaningsih (2013) menunjukkan bahwa "terdapat perbedaan motivasi berpretasi dan prestasi belajar IPS secara simultan antara siswa yang mengikuti model pembelajaran problem solving berbasis budaya local dengan pembelajaran konvensional".

Senada dengan apa yang disampaikan oleh Uno (2015:28-29) bahwa "seorang siswa yang telah termotivasi untuk belajar sesuatu, akan berusaha mempelajarinya dengan baik dan tekun, dengan harapan memperoleh hasil yang baik. Sebaliknya, apabila seorang siswa kurang atau tidak memiliki motivasi untuk belajar, maka dia tidak tahan lama belajar. Berarti motivasi sangat berpengaruh terhadap ketahanan dan ketekunan belajar". 
Perbedaan ini karena siswa yang memiliki motivasi tinggi dapat mempertinggi keaktifannya dalam belajar. Kondisi seperti ini menjadi lebih baik untuk siswa motivasi tinggi yang diajarkan dengan metode problem solving karena didukung pembelajaran dengan berkelompok dan difasilitasi oleh LKS. Siswa yang memiliki motivasi tinggi kelas eksperimen dapat menjelaskan dan mengulang kembali konsep-konsep yang sedang dipelajari pada saat membantu teman-teman dalam kelompoknya.

Hal ini sesuai dengan pendapat Roger dan David Johnson dalam Lie (2002:31) bahwa "untuk mencapai hasil yang maksimal siswa saling ketergantungan positif dan berkomunikasi antar anggota kelompok". Pada pembelajaran konvensional siswa yang memiliki motivasi belajar yang tinggi, terlihat aktif dan menunjukkan keinginan yang kuat untuk berhasil dalam pembelajaran yang disampaikan guru, dapat menjawab pertanyaan yang diberikan guru. Akan tetapi untuk menemukan konsep sendiri atau berkolaborasi dengan teman terbatas karena proses pembelajaran didominasi oleh guru.

Sedangkan hasil pengamatan peneliti terhadap siswa motivasi rendah pada siswa yang diajarkan dengan metode problem solving sebagian kecil belum aktif, duduk berdiam diri memperhatikan teman bekerja dalam kelompok dan sekalikali berjalan-jalan memperhatikan kelompok lain. Sebagian besar lainnya siswa motivasi rendah yang diajarkan dengan metode problem solving sudah bisa mengikuti temanteman dalam kelompoknya untuk bekerjasama disebabkan karena diberikan kesempatan untuk menemukan konsep dengan adanya pengalaman belajar dengan panduan LKS. Selain itu, siswa yang bermotivasi rendah juga mendapatkan bantuan dari siswa yang bermotivasi tinggi untuk memperkuat konsep yang diperoleh.

Hasil penelitian yang dilakukan oleh Mukhlisoh (2014) membuktikan" penerapan metode problem solving berpengaruh terhadap motivasi belajar siswa" Sehingga terlihat jelas beda dari motivasi belajar siswa yang diajarkan dengan metode problem solving 
dengan siswa dengan pebelajaran konvensional. Hal ini sama dengan hasil penelitian Gok dan Silay (2010) menyatakan bahwa "the averages of the experimental group's motivatio, were found to be higher than control group's". Bahasa indonesianya yaitu rata-rata motivasi kelompok eksperimen lebih tinggi daripada kelompok kontrol.

Siswa yang bermotivasi rendah pada kelas kontrol yang diajarkan dengan pembelajaran konvensional terlihat tidak bersemangat dengan pembelajaran perkalian dan pembagian pecahan yang disampaikan. Tidak mau bertanya sedangkan pembelajaran belum mereka pahami. Setiap tugas yang diberikan tidak diselesaikan dengan baik, sebagian mengharapkan bantuan teman untuk menyelesaikan tugas tersebut. Belum menunjukkan keinginan untuk berhasil dalam belajar, terlihat dari cara mereka yang tenang-tenang saja terhadap hasil belajar yang rendah. Inilah yang menyebabkan perbedaan hasil belajar perkalian dan pembagian pecahan siswa motivasi tinggi lebih baik daripada siswa motivasi rendah.
Berdasarkan hasil analisis bahwa tidak terdapat interaksi antara metode pembelajaran dan motivasi terhadap hasil belajar perkalian dan pembagian pecahan siswa. Sama halnya yang telah dibuktikan oleh Suhendri dan Mardalena (2015) dalam penelitiannya "tidak terdapat pengaruh interaksi antara metode pembelajaran dan kemandirian belajar terhadap hasil belajar matematika". Dengan tidak adanya interaksi ini menunjukkan bahwa, tanpa memperhatikan motivasi, pembelajaran dengan metode problem solving dapat diterapkan untuk melihat hasil belajar siswa.

Siswa yang diajar dengan metode problem solving dan konvensional tanpa memperhatikan motivasi tidak saling mempengaruhi terhadap hasil belajar perkalian dan pembagian pecahan siswa. Hal ini menunjukkan bahwa metode pembelajaran tidak tergantung pada motivasi maupun sebaliknya dalam mempengaruhi hasil belajar perkalian dan pembagian pecahan siswa.

Jadi, metode pembelajaran ini dapat digunakan baik untuk siswa bermotivasi tinggi maupun siswa 
bermotivasi rendah untuk melihat hasil belajar perkalian dan pembagian pecahan siswa.

\section{Kesimpulan dan Saran}

\section{a. Kesimpulan}

Berdasarkan data dan analisis data penelitian yang dilakukan, maka hasil dari peneliti ini disimpulkan:

1. Adanya perbedaan hasil belajar perkalian dan pembagian pecahan siswa yang diajar dengan metode problem solving dengan siswa yang diajar dengan metode konvensional.

2. Adanya perbedaan hasil belajar perkalian dan pembagian pecahan siswa motivasi tinggi dengan hasil belajar siswa motivasi rendah.

3. Tidak terdapat interaksi antara Metode Pembelajaran dan Motivasi siswa terhadap hasil belajar perkalian dan pembagian pecahan siswa. Sehingga tanpa memperhatikan motivasipun, metode problem solving bisa diterapkan dalam pembelajaran.

\section{b. Saran}

Beberapa yang dapat disaran kan yaitu:

1. Perlunya dalam pembelajaran di sekolah menggunakan metode pembelajaran problem solving, karena dapat meningkatkan hasil belajar siswa, melatih siswa menjadi aktif, kreatif, termotivasi untuk belajar dan sebaiknya pembelajaran ini di uji cobakan untuk standar kompetensi yang lain.

2. Diharapkan ada pihak lain yang meneruskan penelitian ini, dengan menambahkan materi pembelajaran dan membuat soal tes hasil belajar yang lebih baik.

\section{Daftar Rujukan}

Ainul, Y. 2013. "Pengaruh Metode Pembelajaran Problem Solving Terhadap Hasil Belajar Siswa Pada Standar Kompetensi Dasar-Dasar Kelistrikan di SMK". Jurnal Pendidikan Teknik Elektro. 02(1): 237-245.

Ali, Riasat, dkk. 2010. "Effect of Using Problem Solving Method in Teaching Mathe matics on the Achievement of Mathematics Students". Asian Social Science. 6(2): 67-72

Gök, T \& Silay, I. 2010. "The Effects of Problem Solving Strategies on Students' Achievement, Attitude and Motivation". J. Phys. Educ. 4 (1): 7-21

Lie, Anita. 2002. Cooperative Learning Mempraktikkan Cooperative Learning di Ruang-Ruang Kelas. Jakarta: Grasindo.

Majid, Abdul. 2009. Perencanaan Pembelajaran Mengembang 
kan Standar Kompetensi Guru.

Bandung : Remaja Rosdakarya

Mukhlisoh. 2014. "Pengaruh

Penerapan Metode Problem

Solving Terhadap Motivasi

Belajar Siswa Dalam Mata

Pelajaran IPS Kelas IV MI PUI

Cikaso Kecamatan Kramat mulya Kabupaten Kuningan".

Mulyaningsih, Sri, Setyawati. 2013.

"Pengaruh Model Problem Solving Berbasis Budaya Lokal terhadap Motivasi Berprestasi dan Prestasi Belajar IPS". eJournal Program Pascasarjana Universitas Pendidikan Ganesha Program Studi Pendidikan Dasar. 3

Pait, I Made. 2012. "Pengaruh Model Pembelajaran Problem Solving Dan Penalaran Formal Terhadap Prestasi Belajar Matematika Bagi Siswa Sekolah Menengah Pertama". (hlm. 1-19). Program Studi Teknologi Pembelajaran Program Pascasarjana Univer sitas Pendidikan Ganesha

Polya, G. 1973. How To Solve It. New Jersey: Princeton Univer sity Press

Suhendri, Huri dan Mardalena, Tuti. 2015. "Pengaruh Metode Pembelajaran Problem Solving Terhadap Hasil Belajar Matematika Ditinjau Dari Kemandirian Belajar". Jurnal FormatifI, 3(2): 105-114.

Suherman, Erman, dkk. 2003. Strategi Pembelajaran Matema tika Kontemporer. Bandung: Jurusan Pendidikan Matema tika Universitas Pendidikan Indonesia

Sukayati \& Marfua. 2009. Pembe lajaran Operasi Hitung Perka lian Dan Pembagian Pecahan di SD. Yogyakarta: PPPPTK Matematika

Sumiati \& Asra. 2009. Metode Pembelajaran. Bandung: CV Wacana Prima

Suwanda. 2011. Desain Eksperimen. Bandung: Alfabeta

Udin, Tamsik dan Hikmah, Nurul. 2013. "Pengaruh Penerapan Metode Problem Solving Terha dap Hasil Belajar Siswa Mata Pelajaran Matematika Pokok Bahasan Pecahan Pada Siswa Kelas IV SD Negeri Legok 1 Kabupaten Indramayu".

Uno, Hamzah B. 2015. Teori Motivasi dan Pengukurannya. Jakarta: Bumi Aksara

Wahyudin. 2008. Kurikulum, Pembe lajaran, dan Evaluasi. Jakarta: CV Ipa Abong

Yamin, Martinis. 2009, Manajemen Pembelajaran Kelas (Strategi Meningkatkan Mutu Pembela jaran). Jakarta: Gunung Persa da (GP Press).

Yasin, Ruhizan, M. 2012. "Effects of Problem-solving Strategies in the Teaching and Learning of Engineering Drawing Subject". Asian Social Science. 8(16):

65-79 